\title{
Phytochemical and Morphological Attributes of St. John's Wort (Hypericum perforatum) Affected by Organic and Inorganic Fertilizers; Humic Acid and Potassium Sulphate
}

\author{
Helaleh Sadat KABOLI FARSHCHI*, Majid AZIZI ARANI, \\ Seyyed Hossein NEMATI \\ ${ }^{I}$ Ferdowsi University of Mashhad, Faculty of Agriculture, Department of Horticulture, Mashhad, Iran; \\ helale.farshchi@yahoo.com (*correspondingauthor)
}

\begin{abstract}
This experiment was designed to evaluate the effects of organic (liquid humic acid) and inorganic (potassium sulphate) on phytochemical and morphological attributes of St. John's Wort (Hypericum perforatum). Thus, a research was conducted in a factorial experiment $(3 \times 3)$ based on completely randomized design with three replications. Treatments consisted of potassium sulphate $\left(K_{x}\right)$ at three concentrations $\left(0,60\right.$ and $\left.100 \mathrm{Kg} \cdot \mathrm{h}^{1}\right)$ which were treated before flowering and humic acid $\left(\mathrm{H}_{\mathrm{x}}\right)$ at three concentrations $\left(0,20\right.$ and $40{\mathrm{~L} \cdot \mathrm{h}^{-1}}^{-1}$ which were fertigated four times of 15days intervals. Results showed that the plant stem height, number of flowering stems and number of flowers were significantly affected by simple effect of each fertilizers $(\mathrm{p}<0.01)$, while their interaction effect was not significant for the plants height. The highest contents of fresh and dry weight were achieved under the highest amounts of fertilizers $\left(\mathrm{K}_{100}\right.$ and $\mathrm{H}_{40}$ ). The highest stem height, number of flowers and number of flowering stems also belonged to these treatments. Increment of applied fertilizers led to increase of obtained essential oils, so that application of these fertilizers simultaneously increased the essential oil content up to 6-fold. Regarding the antioxidant activity, applied fertilizers at their high levels showed significant effects on decrease of $\mathrm{EC}_{50}$, which means the increment of antioxidant activity of $H$. perforatum.
\end{abstract}

Keywords: antioxidant activity, essential oil content, yield

\section{Introduction}

Medicinal and aromatic plants can play an important role in commercial crops, which also represent a safe alternative for chemical pharmaceutical industries. St. John's Wort (Hypericum perforatum L.) due to its therapeutic efficacy has been used for decades in folk medicine (Ang et al., 2002; Barnes et al., 2001) and is considered as a promising medicinal plant with valuable potential as a source of hypericin, essential oils and antioxidants (Cellarova et al., 1995). In recent years, the consumption of these plant-derived products has increased dramatically and presently it is one of the most consumed medicinal plant worldwide (Wills et al., 2000). Hypericum extracts show significant antioxidant activity both in vitro and in cell systems, inhibiting free radical generation and lipid peroxidation (Almeida et al., 2009; Benedi et al., 2004;
Zheleva-Dimitrova et al., 2010). It also has been used in herbal medicine, externally for the treatment of skin wounds, eczema, burns and, internally, for disorders of the central nervous system, alimentary tract and other purposes (Barnes et al., 2001; Gioti et al., 2009).

Fertilizer treatment is known to be one of the main factors increasing the yield of plants (Gul et al., 2011). It affects the accumulation, mineralization of organic matter added to the soil and determines plant production potential. Fertilization also determines the concentration of bioactive plant chemicals (Said-Al Ahl et al., 2007). Thus, the improvement of plant nutrition can contribute to increased morphological and phytochemical attributes of plants.

Reports have shown that humic acid is one of the humic fractions of the soil organic matter that is responsible for the generic improvement of soil fertility and improved 
its productivity (Fortun et al., 1989). Accordingly, this material possesses many beneficial agricultural properties, so that it can participate actively in the decomposition of organic matters and minerals. In addition, it improves soil structure and changes physical properties of soil, promote the chelation of many elements and make these available to plants (Said-Al Ahl et al., 2009). Its positive effects were also reported in vitro and in vivo by Yildirim (2007) which resulted in increase of quality and quantity of potato. Cacilia et al. (2011) ferigated different levels of humic acid on Thymus vulgaris and found that applied treatment increased wet and dry weight of plant and antioxidant activity of Thymus vulgaris leaves extract. They also showed that essential oils content decreased under the mentioned treatment. Increase of humic acid levels from 0 to $40 \%$ led to increment of wet and dry weight of Ocimum santum and finally increased the plant yield (Prabhu et al., 2010).

Potassium fertilization is also one of the methods which have great influence on all agronomic variables of yield and chemical constituents of aromatic and medicinal plants. This element $(\mathrm{K})$ is involved in the growth of meristematic tissue and is indispensable for the maintenance of cell turgor pressure, which is required for cell expansion (Rogalski, 1994; Özgüven et al., 2008). The use of $\mathrm{K}$ is especially important when high yield is expected (Defan et al., 1999). The effect of this element has been reported by many researchers on onion (Thabet et al., 1994), Pyrethrum spp. (Sastry and Singh, 1990), Achillea millefolium (Lieres et al., 1994) and Calendula officinalis (Lieres et al., 1994). Their results showed a positive yield response to potassium fertilizer application. Increasing evidence also suggests that mineral nutrients play a critical role in plant stress resistance. Out of all the mineral nutrients, potassium $(\mathrm{K})$ plays a particularly critical role in plant growth and metabolism, and it contributes greatly to the survival of plants. The importance of $\mathrm{K}$ fertilizer for the formation of crop production and its quality is also known (Wang et al., 2013).

However, studies on agronomic factors such as application of potassium and humic acid as well as nitrogen fertilization on yield, essential oils and antioxidant activity of $H$. perforatum have not been investigated thoroughly until now. This study was designed to study the effect of using humic acid and potassium sulphate on the morphological and phytochemical characteristics of Hypericum perforatum medicinal plant.

\section{Materials and methods}

Plant material

The plant material was prepared from Science and Technology Park in Khorasan-e Razzavi-Mashhad. In spring, the plants were transplanted into the field of Faculty of Horticulture, Ferdowsi University of Mashhad, for fertilization treatments.

The experimental layout was factorial in a complete randomized design (CRD), with three replications. Potassium sulphate $\left(\mathrm{K}_{2} \mathrm{SO}_{4}\right)$ was applied at the rates of 0.0 $\left(\mathrm{K}_{0}\right), 60\left(\mathrm{~K}_{60}\right)$ and $100\left(\mathrm{~K}_{100}\right) \mathrm{kg} \cdot \mathrm{ha}^{-1}$. The other treatment was humic acid, which was applied at three rates of $0\left(\mathrm{H}_{0}\right)$, $20\left(\mathrm{H}_{20}\right)$ and $40\left(\mathrm{H}_{40}\right)$ L.ha' ${ }^{-1}$. Plants were treated at two stages, before flowering by potassium fertilizer and fertigated four times of 15-days intervals with humic acid.

Besides the wet and dry weight, plant number of flowers, stem height and number of flowering stems were determined at the end of the growing stage. To extract and quantify the essential oils, a weight of $100 \mathrm{~g}$ of dried herb were subjected to hydro-distillation for 3 hours using a Clevenger apparatus, according to British Pharmacopoeia (1963). Essential oil percentage of each treatment was determined and expressed as (\%), while essential oil yield per plant can be expressed as ml.plant ${ }^{-1}$. The essential oils of each treatment were collected and dehydrated over anhydrous sodium sulphate.

Preparation of methanol extract

The plant materials ( $20 \mathrm{~g}$ of powdered material) were extracted with $200 \mathrm{ml}$ of methanol. Containers stayed on the shaker for 24 hours. This was repeated three times. The obtained methanol extracts passed through Whatman filter paper No. 1. The filtrates obtain Determination of antioxidant activity.

The antioxidant activity of Hypericum perforatum extracts was determined by neutralizing properties of free radical scavenging DPPH method (Liu, 2004). Thus, 100 $\mathrm{ml}$ of the extract was centrifuged and $2900 \mathrm{ml}$ of DPPH solution was added. Mixture was quickly stirred and maintained at room temperature for $15 \mathrm{~min}$ in the dark. Decrease in absorption was determined at a wavelength of $515 \mathrm{~nm}$ by a spectrophotometer (model uv-1800 PC, Japan). In this study, results were evaluated as relative activities against $\alpha$-tocopherol, such served as positive control. Therefore, the antioxidant capacity of the extracts was calculated and expressed as the percent inhibition of DPPH.

$$
\begin{aligned}
& \% D P P H s c=\left(A_{\text {cont }}-A_{\text {samp }}\right) \times 100 / A_{\text {cont }} \\
& \mathrm{A}_{\text {samp }}=\mathrm{DPPH}+\text { Absorption of the sample } \\
& \mathrm{A}_{\text {cont }}=\text { Absorption of DPPH }
\end{aligned}
$$

Percentage of inhibition $=\%$ DPPHsc

\section{Results and discussion}

The ANOVA indicated that most of measured attributes of Hypericum perforatum plant were significantly affected by both treatments. Data presented in Tab. (1) revealed that the highest stem $(91.6 \mathrm{~cm})$ was recorded at the highest level of potassium sulphate $\left(\mathrm{K}_{100}\right)$ treatment, while the smallest height $(60.4 \mathrm{~cm})$ was recorded in the lowest level of potassium sulphate $\left(\mathrm{K}_{0}\right)$ treatment. On the other hand, the highest stem $(80.33 \mathrm{~cm})$ was achieved with the highest level of humic acid treatment. No significant difference was observed between the highest level of humic acid $\left(\mathrm{H}_{40}\right)$ and the second level $\left(\mathrm{H}_{20}\right)$, while both mentioned levels showed a significant difference with the control plants $\left(\mathrm{H}_{0}\right)$. This means that the control plants possessed the lowest stem height $(66.7 \mathrm{~cm})$.

Simple effect of potassium sulphate and humic acid fertilizers were significant for the number of flowering stems, but their interaction effect was not significantly 
328

different. The highest number of flowering stems (106 stems per plant) under potassium sulphate treatment was obtained with the highest level of this treatment, while the lowest number (31.00 stems per plant) was recorder for the control plants. Regarding the humic acid treatment, the most number of flowering stems (68.22 stem per plant) and the least number ( 50.00 stems per plant) were recorded in the levels of $\mathrm{H}_{40}$ and $\mathrm{H}_{0}$, respectively. Our results were in agreement with results reported by Badawy et al. (2009). They stated that levels of potassium fertilizer significantly increased the stem height and number of flowering stems in Artemisia annua plant. Mert (2008) also reported that increment of potassium fertilizer significantly led to increase of stem height and number of flowering stems in all Artemisia annua ecotypes. Arancon et al. (2006) also showed that application of humic acid affected the strawberry stems' height. Results of this experiment also showed a significant difference between levels of potassium sulphate and humic acid for measured number of flowers (Tab. 1).

Tab. 1. Effect of potassium sulphate and humic acid fertilizers on morphological attributes

\begin{tabular}{cccc}
\hline Treatments & $\begin{array}{c}\text { Stem height } \\
(\mathrm{cm})\end{array}$ & $\begin{array}{c}\text { Flowering } \\
\text { stem }\end{array}$ & $\begin{array}{c}\text { Number of } \\
\text { flowers }\end{array}$ \\
\hline $\mathrm{K}_{100}$ & $91.6^{\mathrm{a}}$ & $106^{\mathrm{a}}$ & $24.33^{\mathrm{a}}$ \\
$\mathrm{K}_{60}$ & $69.6^{\mathrm{b}}$ & $44.00^{\mathrm{b}}$ & $18.3^{\mathrm{b}}$ \\
$\mathrm{K}_{0}$ & $60.4^{\mathrm{c}}$ & $31.00^{\mathrm{c}}$ & $15.53^{\mathrm{b}}$ \\
$\mathrm{H}_{40}$ & $80.33^{\mathrm{a}}$ & $68.22^{\mathrm{a}}$ & $34.33^{\mathrm{a}}$ \\
$\mathrm{H}_{20}$ & $74.6^{\mathrm{a}}$ & $62.77^{\mathrm{a}}$ & $17.92^{\mathrm{b}}$ \\
$\mathrm{H}_{0}$ & $66.7^{\mathrm{b}}$ & $50.00^{\mathrm{b}}$ & $5.64^{\mathrm{c}}$ \\
\hline
\end{tabular}

Means with the same letters are not significantly different

Results indicated that potassium sulphate and humic acid significantly affected wet and dry weight of $H$. perforatum in the first and second cuttings $(\mathrm{p}<0.01)$. In the first cutting, the highest ( $440 \mathrm{~g}$ per plant) and the lowest ( 44.6 g per plant) wet weight were recorded in the $\mathrm{K}_{100} \mathrm{H}_{40}$ treatment and control plants, respectively (Fig. 1). Regarding the dry weight of the first cutting, the same result was also observed for the $\mathrm{K}_{100} \mathrm{H}_{40}(84.4 \mathrm{~g}$ per plant $)$ and control (8.90 g per plant) plants (Fig. 2). The highest wet ( $570 \mathrm{~g}$ per plant) and dry (105.5 g per plant) weight of the second cutting were obtained from plants treated with $\mathrm{K}_{100} \mathrm{H}_{40}$ and the lowest wet (110.9 g per plant) and dry weight (21.50 g per plant) from control ones (Fig. 3 and 4$)$.

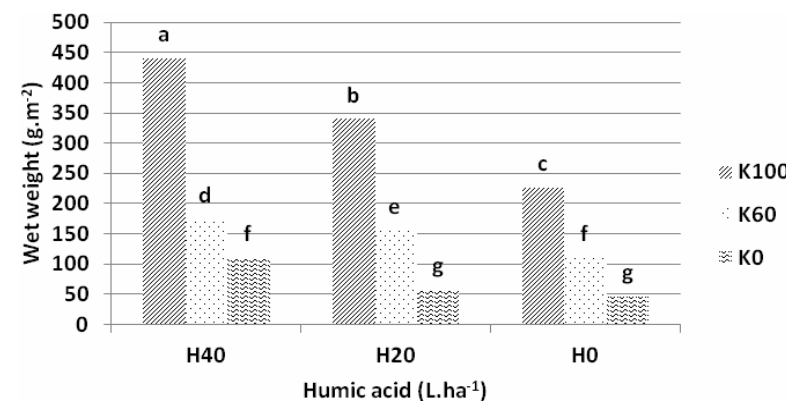

Fig. 1. Effect of humic acid and potassium sulphate on wet weight in the first cutting

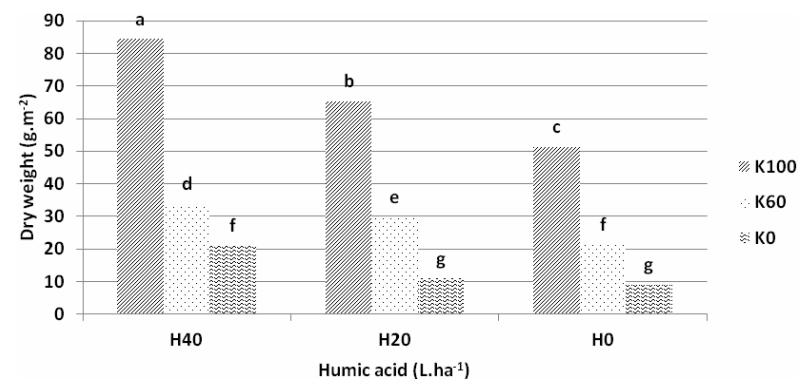

Fig. 2. Effect of humic acid and potassium sulphate on dry weight in the first cutting

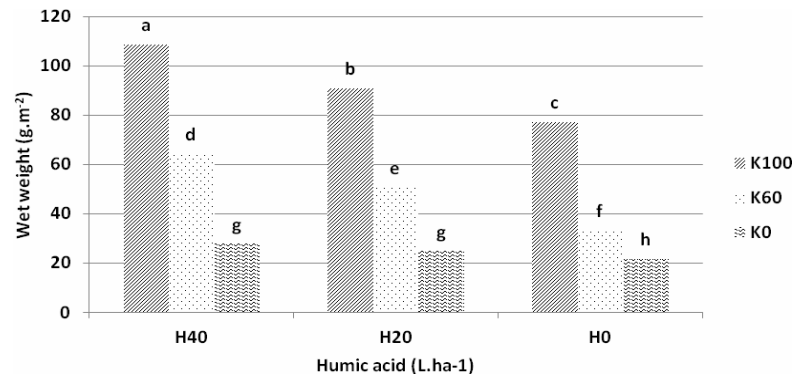

Fig. 3. Effect of humic acid and potassium sulphate on dry weight in the second cutting

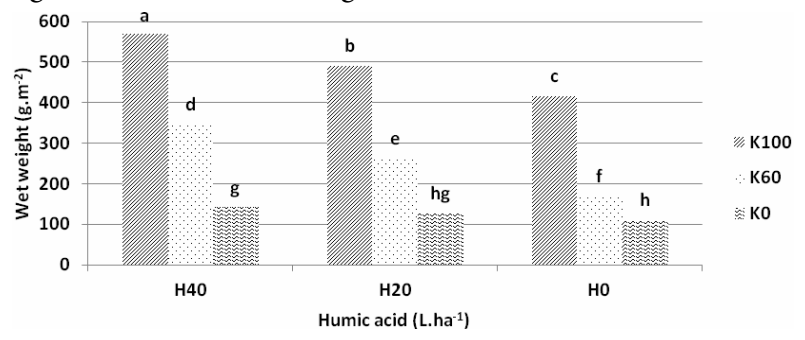

Fig. 4. Effect of humic acid and potassium sulphate on wet weight in the second cutting

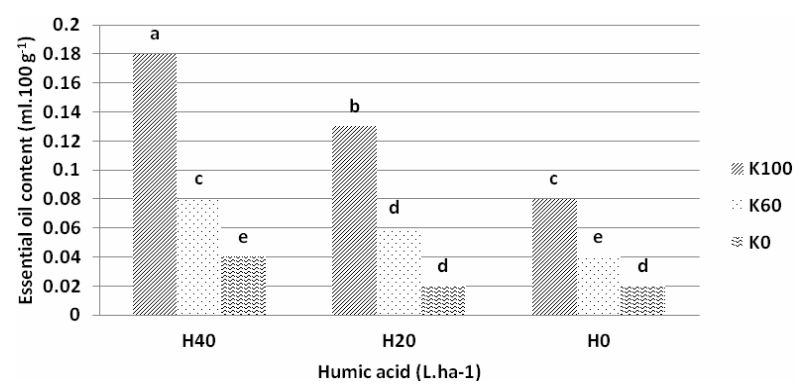

Fig. 5. Effect of humic acid and potassium sulphate on essential oils content

Antioxidant activity

The DPPH method for evaluation of antioxidant activity reflects the ability of the present compounds to scavenge hydrophilic free radicals (Zheng and Wang, 2001). DPPH inhibition was investigated and the results were evaluated as relative activities against $\alpha$-tocopherol as positive control (Tab. 2).

A lower $\mathrm{EC}_{50}$ indicates a higher antioxidant activity (Maisuthisakul and Pongsawatmanit, 2007). As shown in Tab. 2, the least $\mathrm{EC}_{50}$, which indicates the highest 
antioxidant activity, belonged to plants treated with potassium sulphate at level of $100 \mathrm{~kg} \cdot \mathrm{ha}^{-1}$. Control plants possessed the least antioxidant activity and showed no significant difference compared with plants treated with 60 $\mathrm{kg} \cdot \mathrm{ha}^{-1}$ of this fertilizer.

Humic acid had a significant effect on antioxidant activity of $H$. perforatum. The lowest value of $\mathrm{EC}_{50}$ was related to the highest level of humic acid, while the highest value of $\mathrm{EC}_{50}$ was obtained from control plants. There was also significant difference between control and two other levels $\left(20\right.$ and 401. ha $\left.^{-1}\right)$ of humic acid.

Thus, applied fertilizers at their high levels showed significant effects on decrease of $\mathrm{EC}_{50}$, which means the increment of antioxidant activity of $H$. perforatum. The high antioxidant activity of this medicinal plant is the reason of flavonoids and phenols existence (Butterweck, 2003). It seems that application of these fertilizers have led to increment of the mentioned secondary metabolites and followed by an increase of antioxidant activity in comparison with control plants. Totally, $H$. perforatum possessed a high antioxidant activity. Results of this study were in accordance with reports of Gioti et al. (2009). One of the destructive effects of free radicals production in human body is severe damage to nervous system (Behl and Mosmann, 2002). Thus, high antioxidant activity of this plant extract can inhibit most of diseases and more works to increase antioxidant activity power of this important medicinal plant seems to be necessary.

Tab. 2. Calculated $\mathrm{EC}_{50}$ and its comparison with $\alpha$-tocopherol $\mathrm{EC}_{50}$ as positive control

\begin{tabular}{cccc}
\hline Treatment & $\begin{array}{c}\text { Calculated } \\
\text { EC50 (m.ml-1) }\end{array}$ & $\begin{array}{c}\alpha \text {-tocopherol } \\
\text { EC50 }\end{array}$ & $\begin{array}{c}\text { Calculated EC50/ } \\
\alpha \text {-tocopherol } \\
\text { EC50 }\end{array}$ \\
\hline 0 & 0.05 & 0.0038 & 13.158 \\
$0 \times 20$ & 0.043 & 0.0038 & 13.579 \\
$0 \times 40$ & 0.041 & 0.0038 & 10.789 \\
$60 \times 0$ & 0.041 & 0.0038 & 7.895 \\
$60 \times 20$ & 0.037 & 0.0038 & 9.737 \\
$60 \times 40$ & 0.033 & 0.0038 & 6.842 \\
$100 \times 0$ & 0.032 & 0.0038 & 8.421 \\
$100 \times 20$ & 0.005 & 0.0038 & 1.316 \\
$100 \times 40$ & 0.005 & 0.0038 & 1.316 \\
\hline
\end{tabular}

Essential oil content

As shown in Fig. 5, increment of applied fertilizers led to an increase of the obtained essential oils. Although the essential oils content of this plant is low, application of these fertilizers simultaneously increased the essential oils content up to 6 -fold. The highest essential oils content was achieved at the highest levels of fertilizers, potassium sulphate and humic acid. Control plants possessed the lowest essential oil content under both treatments. Recorded essential oils content of this study is in accordance with the results of Schwob et al. (2004). Hendway and Khalid (2009) investigated the effect of simultaneous application of macro and inorganic elements on Matricaria chamomilla. They found that simultaneous application of those fertilizers led to a more significant increase of essential oil content, rather than separately applicated fertilizers. They suggested that increase of flower number and dimensions led to an increase of essential oil content. Effect of potassium and nitrogen fertilizers on Tanacetum balsamita was also investigated by Hasanpour et al. (2008) and they reported that the highest essential oil content was achieved under higher levels of fertilizers. They stated that suitable nutrition would result in promotion of involved secondary metabolites synthesis pathways. It seems that potassium is consumed in enzymes structure involving biochemical pathways of secondary metabolites synthesis. They also reported that imbalance of fertilizers would have similar effects as nutrition shortage on yield, followed by secondary metabolites production, such as essential oil content.

\section{Conclusions}

Based on recorded data of the present study, application of the mentioned fertilizers separately or simultaneously caused the increase of this important medicinal plant wet and dry weight, and finally the yield. Number of flowers, stem height and flowering stems reached the highest value at the highest level of both fertilizers $\left(\mathrm{K}_{100} \mathrm{H}_{40}\right)$. As potassium plays an important role in the development of reproductive parts of plants, it might be one of the reasons of the above mentioned increase. The highest essential oils content was recorded at up levels of both fertilizers $\left(\mathrm{K}_{100} \mathrm{H}_{40}\right)$. Since the most essential oils content accumulates in the flowering stems, an increase of these stems' height and a larger number of flowers would lead to an increase of essential oils content of $H$. perforatum. Antioxidant activity of this plant is flavonoids contributed. It seems that application of these fertilizers increased the antioxidant activity by an increase of this pigment content.

\section{References}

Almeida IF, Fernandes E, Lima JL, Costa PC, Bahia MF (2009). In vitro protective effect of Hypericum androsaemum extract against oxygen and nitrogen reactive species. Basic Clin Pharmacol Toxicol 105:222-227.

Ang CY, Cui Y, Chang HC, Luo W, Heinze TM, Lin LJ (2002). Determination of St. John's Wort components in dietary supplements and functional foods by liquid chromatography. J AOAC Int 85:1360-1369.

Arancon N, Edwards C, Lee S, Byrne R (2006). Effects of humic acids from vermicomposts on plant growth. Eur J Soil Biol 42:S65-S69.

Badawy EM, El-Maadawy EIM, Heikal AA (2009). Effect of nitrogen, potassium levels and harvesting date on growth and essential oil productivity of Artemisia. The $4^{\text {th }}$ Conference on Recent Technologies in Agriculture, 600-616.

Barnes J, Anderson LA, Phillipson D (2001). St John's Wort (Hypericum perforatum L.): A review of its chemistry, pharmacology and clinical properties. J Pharm Pharmacol 53:583-600.

Behl C, Mosmann B (2002). Antioxidant neuroprotection in Alzheimer's disease as preventive and therapeutic approach. Free Radical Biol Med 33:182-191. 
330

Benedi J, Arroyo R, Romero C, Martin-Aragon S, Villar AM (2004). Antioxidant properties and protective effects of a standardized extract of Hypericum perforatum on hydrogen peroxide-induced oxidative damage in PC12 cells. Life Sci 75(10):1263-1276.

British Pharmacopoeia (1963). Determination of volatile in drugs. The Pharmaceutical Press, London.

Butterweck V (2003). Mechanism of action of St. John's Wort in depression: What is known? CNS Drugs 17:539-562.

Cacilia R, Juarez R, Craker L, Mendoza A (2011). Humic substances and moisture content in the production of biomass and bioactive constituents of Thymus vulgaris. L. Articulo Cientifico 34(3):183-188.

Cellarova E, Kimakova K, Daxnerova Z, Martonfi P (1995). Hypericum perforatum (St John's Wort): In vitro culture and the production of hypericin and other secondary metabolites. Biotechnol Agric Forestry 33:261-275.

Defan TA, Kholi HMA, Rifaat MGM, Allah AEA (1999). Effect of foliar and soil application of potassium on yield and mineral content of wheat grains grown in sandy soils. Egypt J Agric Res 77:513-522.

Fortun C, Fortun A, Almendros G (1989). The effect of organic materials and their humified fractions on the formation and stabilization of soil agger gates. Sci Total Environ 81/82:561568.

Gioti EM, Fiamegos YC, Skalkos DC, Stalikas CD (2009). Antioxidant activity and bioactive components of the aerial parts of Hypericum perforatum L. from Epirus, Greece. Food Chem 117:398-404.

Gul H, Said A, Beena S, Fida M, Ijaz A (2011). Effect of Foliar Application of Nitrogen, Potassium and Zinc on Wheat Growth. ARPN J Agric Biol Sci 6(4):56-59.

Hassanpouraghdam MB, Tabatabaie SJ, Nazemiyeh H, Aflatuni A (2008). $\mathrm{N}$ and nutrition levels affect growth and essential oil content of costmary (Tanacetum balsamita L.) Food Agric Environ 6(2):150-154.

Hendway S, Khalid Kh (2009). Effect of chemical and organic fertilizer on yield and essential oil of chamomile flower heads. Med Aromat Plant Sci Biotechnol 5(1):43-48.

Lieres AV, Volkmann B, Von-Lieres A (1994). Relationship between fertilizer, nutrient withdrawal and composition of different medicinal plants in a pot experiment. Kongress band 1994 Jena. 19-24.

Liu RH (2004). Potential synergy of phytochemicals in cancer prevention: Mechanism of action. Nutrition 134(Suppl. 12):3479S-3485S.

Maisuthisakul PSM, Pongsawatmanit R (2007). Assessment of phenolic content and free radical-scavenging capacity of some Thai indigenous plants. Food Chem 100:1409-1418.

Mert A (2008). The effect of some agronomic practices on yield and yield components with quality of Artemisia annua L., PhD Thesis. Cukurova University, Institute of Natural and Applied Sciences, Adana, Turkey. (Cited after Özgüven et al., 2008, Ind Crops Prod 27(1):60-64).
Özgüven M, Sener B, Orhan I, Sekeroglu N, Kirpik M, Kartal M, Pesin I, Kaya Z (2008). Effect of varying nitrogen doses on yield, yield components and artemisinin content of Artemisia anuua L. Ind Crops Prod 27(1):60-64.

Prabhu M, Ramesh Kumar A, Rajamani K (2010). Influence of different organic substances on growth and herb yields of sacred basile (Ocimum basilicum L.). Indian Journal of Agricultural Research 44(1):48-52.

Rogalski L (1994). Influence of supplementary foliar spray nutrition with plant protection on yield of winter wheat. Acta Academia Agri Tech Olsteninsis 57:111118.

Said-Al Ahl H, Hasnaa AH, Ayad S, Hendawy SF (2009). Effect of potassium humate and nitrogen fertilizer on herb and essential oil of Oregano under different irrigation intervals. J Appl Sci 2(3):319-323.

Sastry KP, Singh SP (1990). The effect of phosphorus and potassium applications on the flower yields of pyrethrum. Pyrethrum-Post 17(4):130-132.

Schwob I, Bessiere J, Masotti V, Viano J (2004). Change in essential oil composition in Saint John's Wort (Hypericum perforatum) aerial parts during its phonological cycle. Biochem Sys Ecol 32:735-745.

Thabet EMA, Abdallah AAG, Mohamed AR (1994). Productivity of onion grown in reclaimed sandy soil using tafla as affected by water regimes and nitrogen levels. Ann Agric Sci 39(1):337-344.

Wang M, Zheng Q, Shen Q, Guo SH (2013). The Critical Role of Potassium in Plant Stress Response. Int J Mol Sci 14:73707390.

Wills RBH, Bone K, Morgan M (2000). Herbal products: Active constituents, modes of action and quality control. Nutritional Res Rev 13:47-77.

Yildirim E (2007). Foliar and soil fertilizations of humic acid affect productivity and quality of tomato. Acta Agric Scand Sect Soil Plant Sci 57:182-186.

Zheleva-Dimitrova D, Nedialkov P, Kitanov G (2010). Radical scavenging and antioxidant activities of methanolic extracts from Hypericum species growing in Bulgaria. Pharmacognosy Mag 6:74-78.

Zheng W, Wang SY (2001). Antioxidant activity and phenolic compounds in selected herbs. Agric Food Chem 49(11):5165517. 